\title{
EN CEREMONIA INDÍGENA HABRÍAN SACRIFICADO A NIÑO DE SIETE
}

\author{
LA MACHI QUE ORDENÓ EL BÁRBARO ACTO Y SUS CÓMPLICES \\ FUERON ENTREGADOS A LA JUSTICIA
}

Expresiones de barbarie que aparentemente ya habían sido borradas por la civilización, han aflorado de nuevo en el ancestro indígena. Personas que por diversos motivos han sido admitidas en las ceremonias tradicionales de las tribus, ya habían informado acerca de las prácticas salvajes de los ritos aborígenes, tales como quemar animales vivos o extraerles el corazón palpitante y beber su sangre.

Pero lo que seguramente nadie sospechaba era la posibilidad de que los indios practicasen sacrificios humanos. Sin embargo, hace algunos días se tuvo noticias, a base de un escalofriante relato hecho por uno de los indígenas de la costa, que en una ceremonia se había dado muerte a un menor.

\section{LOS HECHOS}

Con motivo de los fenómenos telúricos que asolaron la región del litoral, los indígenas realizaron guillatunes y otros actos destinados a aplacar la ira de los espíritus y lograr la cesación de los movimientos de la tierra.

Pero como se trataba de un hecho que había causado pavor entre las tribus y era necesario dejar satisfechos a los dioses que provocan estas calamidades, la machi Luisa María Namuncura Añén, concibió la idea o seguramente solo aplicó el ceremonial clásico, y ordenó que se sacrificase a un ser humano. Fue elegido como víctima el niño José Painecura Painecura, de 7 años. Varios indígenas llegaron hasta la ruca en que se encontraba el menor y solicitaron su entrega al encargado o pariente del niño Juan José Painecura Painao, quien sin dificultades habría accedido a la petición de la hechicera.

El niño habría sido llevado al lugar en que se desarrollaba la ceremonia, 7 kilómetros al sur de Puerto Saavedra y lanzado al mar. Hay asimismo, otra versión en el sentido de que el niño habría sido muerto a puñaladas durante la ceremonia.

Impuestos de algunos antecedentes sobre el salvaje hecho, Carabineros procedió a detener a la machi Luisa María Namuncura, a su hermana Juana 
Namuncura, Juan Paiñao, quien habría lanzado el pequeño al océano y Juan José Painecura, directamente culpable por haber hecho entrega del menor.

Los implicados pasaron ayer a disposición del Juzgado de Imperial, según informaciones proporcionadas por nuestro corresponsal en la citada localidad.

También ha llegado a la zona Rosa Painecura Ancao, madre de la víctima. Esta persona trabaja en Concepción y regresó de inmediato al saber la suerte que había corrido su hijo en el bárbaro rito.

En ceremonia indígena habrían sacrificado a niño de siete. Diario Austral de Temuco, 21 de junio de 1960. 6 p. 